\title{
MURDER IN \\ THE CATHEDRAL AND \\ THE COCKTAIL \\ PARTY
}

Text and Performance

WILLIAM TYDEMAN

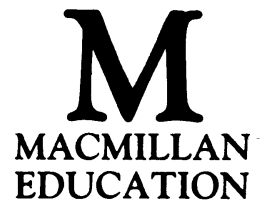




\section{(C) William Tydeman 1988}

All rights reserved. No reproduction, copy or transmission of this publication may be made without written permission.

No paragraph of this publication may be reproduced, copied or transmitted save with written permission or in accordance with the provisions of the Copyright Act 1956 (as amended), or under the terms of any licence permitting limited copying issued by the Copyright Licensing Agency, 33-4 Alfred Place, London WC1E 7DP.

Any person who does any unauthorised act in relation to this publication may be liable to criminal prosecution and civil claims for damages.

First published 1988

Published by

MACMILLAN EDUCATION LTD

Houndmills, Basingstoke, Hampshire RG21 2XS

and London

Companies and representatives

throughout the world

Typeset by Wessex Typesetters

(Division of The Eastern Press Ltd)

Frome, Somerset

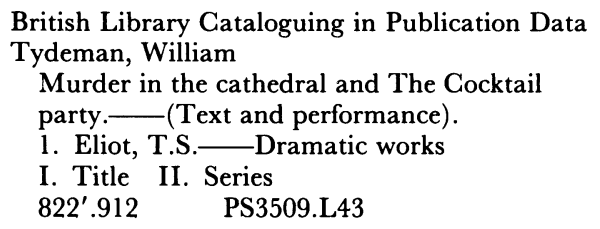

ISBN 978-1-349-08939-0

ISBN 978-1-349-08937-6 (eBook)

DOI 10.1007/978-1-349-08937-6 


\section{GONTENTS}

Acknowledgements

General Editor's Preface $\quad 7$

PART ONE: TEXT

1 Introduction 9

2 Drama and Doctrine 19

3 Drama and Ritual 28

4 Drama and Realism 36

5 Drama and Personality 42

6 Drama and Poetry 50

PART TWO: PERFORMANCE

7 Introduction $\quad 59$

8 The Author's Role 66

9 The Directors' Role $\quad 70$

10 The Players' Roles $\quad 76$

11 The Critics' Verdicts 86

$\begin{array}{ll}\text { Reading List } & 94\end{array}$

Index of Names 96

Illustrations will be found in Part Two. 


\section{AGKNOWLEDGEMENTS}

My thanks are due once again to the General Editor and to Beverley Tarquini for their advice, patience and encouragement, and to my colleagues in the Department of English at the University College of North Wales for undertaking duties respite from which enabled me to take a term's Study Leave in the summer of 1987. I am also indebted to the authors of the invaluable books, articles and reviews cited in the text and in the list of suggested reading at the end of the book. References to Eliot's works are taken with permission from the Collected Poems and Plays (1969), from Selected Essays (1932, enlarged edn, 1951) and from On Poetry and Poets (1957).

The author and publishers wish to thank the following who have kindly given permission for the use of copyright material.

Faber and Faber Ltd. and Harcourt Brace Jovanovich, Inc. for excerpts from; Murder in the Cathedral by T. S. Eliot, copyright 1935 by Harcourt Brace, Inc. renewed 1963 by T. S. Eliot; The Cocktail Party by T. S. Eliot, copyright 1950 by T. S. Eliot, renewed 1978 by Esme Valerie Eliot; The Family Reunion by T. S. Eliot, copyright 1939 by T. S. Eliot, renewed 1967 by Esme Valerie Eliot; 'Dialogue on Dramatic Poetry' from Selected Essays by T. S. Eliot, copyright 1950 by Harcourt Brace Jovanovich, Inc., renewed 1978 by Esme Valerie Eliot; and Faber and Faber Ltd. for excerpts from On Poetry and Poets by T. S. Eliot.

Every effort has been made to trace all the copyright holders but if any have been inadvertently overlooked the publishers will be pleased to make the necessary arrangement at the first opportunity. 


\section{GENERAL EDITOR'S PREFACE}

For many years a mutual suspicion existed between the theatre director and the literary critic of drama. Although in the first half of the century there were important exceptions, such was the rule. A radical change of attitude, however, has taken place over the last thirty years. Critics and directors now increasingly recognise the significance of each other's work and acknowledge their growing awareness of interdependence. Both interpret the same text, but do so according to their different situations and functions. Without the director, the designer and the actor, a play's existence is only partial. They revitalise the text with action, enabling the drama to live fully at each performance. The academic critic investigates the script to elucidate its textual problems, understand its conventions and discover how it operates. He may also propose his view of the work, expounding what he considers to be its significance.

Dramatic texts belong therefore to theatre and to literature. The aim of the 'Text and Performance' series is to achieve a fuller recognition of how both enhance our enjoyment of the play. Each volume follows the same basic pattern. Part One provides a critical introduction to the plays under discussion, using the techniques and criteria of the literary critic in examining the manner in which the work operates through language, imagery and action. Part Two takes the enquiry further into the plays' theatricality by focusing on selected productions so as to illustrate points of contrast and comparison in the interpretation of different directors and actors, and to demonstrate how the plays have worked on the stage. In this way the series seeks to provide a lively and informative introduction to major plays in their text and performance.

Michael Scott 